\title{
LANDSCAPE DIVERSITY AND BIODIVERSITY OF FANN MOUNTAINS (TAJIKISTAN)
}

\author{
OIMAHMAD RAHMONOV, LESZEK MAJGIER, WIACZESŁAW ANDREJCZUK, \\ JAROSŁAW BANASZEK, DOMINIK KARKOSZ, TOMASZ PARUSEL, ARTUR \\ SZYMCZYK
}

University of Silesia, Faculty of Earth Sciences, Bedzinska 60, 41-200 Sosnowiec, Poland; e-mail: oimahmad.rahmonov@us.edu.pl

\begin{abstract}
Rahmonov O., Majgier L., Andrejczuk W., Banaszek J., Karkosz D., Parusel T., Szymczyk A.: Landscape diversity and biodiversity of Fann Mountains (Tajikistan). Ekológia (Bratislava), Vol. 32, No. 4, p. 388-395, 2013.

The aim of study is a presentation of main vegetation landscape diversity and biodiversity in case of endemic species in the Fann Mountains area, in horizontal and vertical approach. In terms of biodiversity, the high-mountain ecosystems of Central Asia include the most valuable areas in the world called as hotspot, and also are exposed to intense human pressure causing the destruction of habitats. Vegetation landscapes of Fann Mountains are very diverse because of high-mountain character of this area, local climatic conditions, topography and habitats. That differentiation leads up to biodiversity and formation of unique plant landscapes and endemic species. The vegetation landscapes in altitude order are represented by forbs meadow steppe, thymes, swamp, broad-leaf forest, juniper forests, flood-plain small-leaved forest, tugai, light deciduous forest, pistachio, forbs wormwood, almond, rare vegetation with cushion-shaped species, wormwood eurotia, steppe, thorny grasses with shrub-steppe, rocks and taluses with rare vegetation alpine zones. High level of endemism in Fann Mountains is connected to natural conditions such as geological structure, relief, high-mountain ranges and climate conditions. This fact has an influence on forming mosaic biotops, often isolated by orographic barriers.
\end{abstract}

Key words: biodiversity, Fann Mountains, endemic species, landscape diversity.

\section{Introduction}

In terms of biodiversity, the high-mountain ecosystems of Central Asia belong to the most valuable areas in the world called as hotspot, and are also exposed to intense human pressure which causes the destruction of habitats. Vegetation landscapes of Fann Mountains are very divers according to high-mountain character of this area, local climatic conditions, topography and habitats. That differentiation leads up to biodiversity and formation of unique plant communities and endemic species. High level of endemism in Fann Mountains is connected to natural conditions such as geological structure, high mountains ranges and climate conditions. This fact has an influence on forming mosaic biotops, often isolated by orographic barriers. A problem of landscapes diversity and biodiversity of this region was mentioned in 
many works in the last century (Zakirov, 1955, 1961; Stanyukovich, 1963; Sidorenko et al., 1964; Konnov, 1973; Safarov, 1974; Kamelin, 1979; Kudratov, 1985, Rahmonov et al., 2011a). So there is a need for repeated investigations in this region.

The area of Republic of Tajikistan, with its diverse plant landscapes (in the vertical direction), is characterized by a rich and peculiar vegetation cover. In this relatively small area, more than 5000 species of vascular plants are observed, 850 of which occur only in the territory of Tajikistan or slightly exceed its limits (Abdusalyamov, 1988). Mountain ecosystems of Central Asia are - in terms of biodiversity - one of the most valuable areas of the Earth (Meyers et al., 2000; Mittermeier et al., 2005). One of the reasons for biodiversity and phenomenon of endemism is associated with the presence of orographic barriers such as the Zeravshan Range. High mountain ranges hinder the migration of animal and plant spreading. Consequently, isolated populations can easily evolve into separate species. The great glacial cirques and deep valleys, occurring between mountain ranges, are characterized by specific climatic and soil conditions, which affect the occurrence of the species, which are not found in other ecosystems.

The aim of study is a presentation of vegetation landscapes diversity in the Fann Mountains area in horizontal and vertical approach, and paying detailed attention to occurrences, and confirmation of previously identified endemic species within the ecosystem of Fann Mountain.

\section{Material and methods}

The data was collected in years 2001-2010, partly with the participation of researchers from Medical University in Dushanbe. Investigations were conducted in the area of central part of Zeravshan Botanical Region - Fann Mountains. Research carried out the observation of vegetation landscapes in altitude aspect and determination of species composition within distinguished landscape units. Location of confirmed and identified endemic species was recorded by means of GPS receiver. The digital map of distribution of endemic plant species is at the stage of preparation (Rahmonov et al., 2011b). Detailed information on the occurrences of endemic species are given in the ten-volume of Flora of Tajik SSR. This facilitated the location of these taxa in the study area.

The collected data was analysed by common geobotanical methods. The name of vegetation community comes from dominating species and determination of plants was performed using 10-volume Flora of Tajik SSR (Ovchinnikov, 1957, 1963, 1968, 1975, 1978, 1981; Chukavina, 1984; Kochkareva, 1986; Kinzikaeva, 1988; Rasulova, 1990). In these volumes also is given detailed information on the ecology, biology and distribution of all endemic plants species growing (640 taxa) within the Republic of Tajikistan and its surroundings.

Latin names of species were given after the Flora of Tajik SSR. Names of ecosystems were taken according to Goncharov (1937), Ovchinnikov (1957) and Stanyukovich (1982), while the plant belts were taken according to Stanyukovich (1973). The detailed observations of endemic plant species in the east of province, mainly in the Yagnob River valley and in the upper part of Zeravshan River valley, were carried out by a team of researchers under the direction of M. Kholbegov from the Medical University in Dushanbe (Tajikistan).

Study area

The Fann Mountains are located in Central Asia in the central part of the Zeravshan Mountains (north-west part of Tajikistan). Stretches from the west to the east on the longitudinal section of a length about $300 \mathrm{~km}$ ((within Tajikistan areas)) and the average width of the mountain range here reaches ca $50 \mathrm{~km}$. It is separated from the Turkestan Ridge by the Zeravshan River valley in the north, whereas the Yagnob River valley separates them from the Gissar Ridge in the south (Fig. 1). 


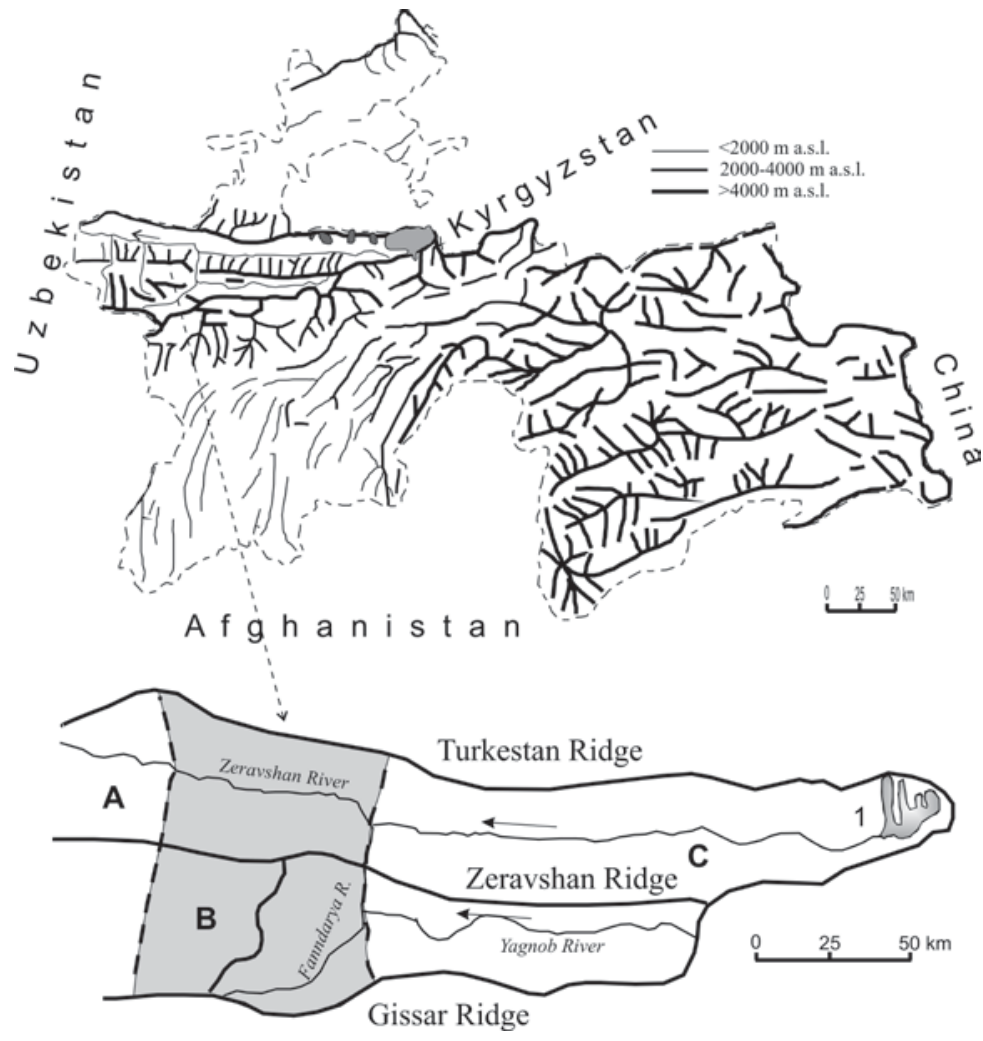

Fig. 1. Distribution of main mountain ridges in the area of Tajikistan (after Atlas of Tajik SSR, 1968) and Zeravshan geobotanical region: A - western sub-region, B -central sub-region (research field), C - eastern sub-region; 1 Zeravshan Glacier.

In this area the average annual rainfall is $400-500 \mathrm{~mm}$ (much of it falls in the spring period) and winter is generally characterized by a small amount of snow. Average summer temperature of July and August is about $15-16^{\circ} \mathrm{C}$ (maximum: $25-26^{\circ} \mathrm{C}$ ), while the average monthly in winter is form -5 to $-8{ }^{\circ} \mathrm{C}$ (coldest January varies from -25 to $-26^{\circ} \mathrm{C}$ ). The length of the period without frost and snow reaches 90-100 days per year (Konnov, 1973).

In terms of geobotanic regionalization of Tajikistan, the study area lies within the Zeravshan Geobotanic District, including mainly the Zeravshan Mountains. Together with the adjacent areas it is characterized by a variety of natural and geographical conditions. Therefore, the district is divided into three geobotanic sub-regions: Western (A), Central (B), and Eastern Zeravshan (C) (see Fig. 1). Investigation was conducted in Central Zeravshan (B) - the area which belongs to central part of Fann Mountains.

\section{Results}

\section{Vegetation}

Within the Fann Mountains region four plant zones are generally distinguished: I - zone of sage and saltwort deserts with domination of Artemisia tenuisecta and A. porrecta (1200- 
$2000 \mathrm{~m}$ a.s.l.), II - zone of sage desert and juniper forests mostly Juniperus seravschanica (2000-2700 m a.s.l), III - zone of steppes juniper forests and torn vegetations with participation of J. turcestanica, Festuca sulcata, Onobrychis echidna (2700-3400 m a.s.l.), IV - zone of cushion plant formation and torn vegetations (3400-4000 m a.s.l.) with Oxytropis savellanica, Potentilla flabellate and many species from Cousina genus.

The relief differentiation conditioned the formation of micro- and macro-habitats which is due to formation of specific habitat conditions. There is also a huge difference between southern and northern slopes in terms of insolation, humidity and ground stabilization. Differentiation of these contribute to the formation of small vegetation groups within particular plant belts in term of ecological requirements. Our investigations showed high diversity of vegetation patches in Fann Mountains within plant belts. The vegetation landscapes in the order of altitude in this region are represented by the following main ecosystems:

- Wetland (tugai, meadow, swamp)

- $\quad$ Foothill semi-desert and desert (low-grass, saltwort-Artemisia sp, sand)

- Mid-low-mountain semi-savannah (savannoides, forbs and shrub)

- Mid-mountain xerophytic light forest ecosystems (forbs, Artemisia sp., Pistacia sp., Amygdalus sp.)

- Mid-mountain mesophyllic forest ecosystems (broad-leaf and light forest, mesophyllic shrub)

- Mid-mountain conifer forest ecosystems (various-shrub steppe and light forest),

- High mountain meadow and steppe ecosystems (forbs meadow steppe, thymes, swamp)

- High mountain desert ecosystems (rare vegetation with cushion-shaped species, wormwood-teresken steppe, thorny grasses-shrub steppe)

- Nival glacier ecosystems (glaciers and snowfields, rocks and taluses with rare vegetation).

The above-mentioned vegetation landscapes often create isolated islands, characterized by specific features connected with the variability of climate and altitude, and geomorphologic diversity. Consequently, it affects their floristic composition, ecological and biological diversity, as well as morphological adaptation of plant species to the conditions of high mountain climates of arid type.

The Zeravshan-Turkestan Region is also characterized by the presence of desert and semi-desert vegetation, combined with low-grass semi-savannahs, with fragments of xerophytic light forests with Acer turkestanicum and A. regelii. Mixed thermophyllic and micro-thermal juniper forests, combined with cryophytic steppes on the mountain peaks are most common in the mountain part of this region.

\section{Endemic flora}

Within the borders of the Zeravshan geobotanical district (central part of Fann Mts.) was confirmed the occurrences of 135 endemic species of vascular flora. They form 23 families and 80 genera. To families of the largest number of endemic plants belong Leguminosae (35), Cruciferae (12), Labiatae (11), Rosaceae (10), Compositae (10), Gramineae (8), Ranunculaceae (8), Umbelliferae (7), Campanulaceae (6), Limoniaceae (5), Betulaceae (4), Liliaceae (Table 1), whereas 
Ta ble 1. The list of confirmed endemic plant species of Zeravshan geobotanical region (central part - Fann Mountains).

\begin{tabular}{l}
\hline Family/species \\
\hline Gramineae: Poa articulata Ovcz., Festuca squamulosa Ovcz., Zerna Paulsenii (Hack.) Nevski, Roegneria inter- \\
rupta Nevski, Elytrigia setulifera Nevski, Helictotrichon hissaricum (Roshev.) Henr., Piptatherum Fedtschenkoi Ro- \\
shev., P. pamiroalaicum (Grig.) Roshev.
\end{tabular}

Liliaceae: Merendera hissarica Regel, Eremurus hissaricus Vved., Gagea leucantha M. Pop. et Czug., G.minutissima Vved., G. paedophila Vved., Asparagus Komarovianus Vved.

Amaryllidaceae: Allium. darvasicum Regel

Betulaceae: Betula seravschanica V. Vassil., B. alajica Litv., B. pamirica Litv., B. Regeliana V. Vassil.

Santalaceae: Thesium Gontscharovii Bobr.

Polygonaceae: Rheum hissaricum Losinsk., R. Fedtschenkoi Maxim. ex Regel, Polygonum myrtillifolium Kom.

Ranunculaceae: Delphinium propinquum Nevski, D.ternatum Huth., D. Ovczinnikovi Kam. et Pissjauk. ex Kam., Aconitum zeravschanicum Steinb., Anemone seravschanica Kom., Ranunculus baldshuanicus Ovcz. et Koczk., $R$. alpigenus Kom., R. turkestanicus Franch.

Crassulaceae: Pseudosedum condensatum Boriss., P. Fedtschenkoanum Boriss.

Rosaceae: Cotoneaster zeravschanicus Pojark., Potentilla Vvedenskyi Botsch., P. flabellata Regel et Schmalh., P. mollissima Lehm., P. darvasica Juz. ex Botsch., Alchemilla verae Ovcz., A. biradiata Ovcz., A. hissarica Ovcz. et Koczk., Rosa huntica Chrshan., R. achburensis Chrshan.

Cruciferae: Erysimum samarkandicum M. Pop., Cardamine densiflora Gontsch., C. seravschanica Botsch., Parrya fruticulosa Regel et Schmalh., P. runcinata (Regel et Schmalh.) N. Busch, P. turkestanica (Korsh.) N. Busch, Matthiola integrifolia Kom., Iskandera hissarica N. Busch, Draba hissarica Lipsky, D. alticola Kom., Lepidium seravschanicum Ovcz. et Junuss.

Leguminosae: Melissitus iskanderi (Vass.) Latsch., Colutea hybrida Shap., Chesneya kschtutica Rassul. et B. Sharipova, T. macrantha Boriss., Oxytropis Lehmanni Bunge, O. Michelsonii B. Fedtsch., O. lithophila Vass., O. iskanderica B. Fedtsch., O. leptophysa Bunge, Ewersmannia sogdiana Ovcz., Hedysarum Korshinskyanum B. Fedtsch., H. mogianicum B. Fedtsch., Lathyrus mulkak Lipsky, Astragalus macropodium Lipsky, A. czapdarinus Ovcz. et Rassul., A. quisqualis Bunge, A. acormosus N. Basil., A. pauper Bunge, A. Aphanassjievii Gontsch., A. indurescens Gontsch., A. sericeopuberulus Boriss., A. exasperatus N. Basil., A. roschanicus B. Fedtsch., A. intarrensis Franch., A. saratagius Bunge, A. Saratagius v. artschamajani Rassul. subsp. nova in Addenda, A. saratagius v. sarimensis Rassul. subsp. nova in Addenda, A. kschtutensis Rassul., A. urgutinus Lipsky, A. polytimeticus M. Pop., A. Iksanderi Lipsky, A. neurophyllus Franch., A. heterotrichus Gontsch., A. rumpens Meffert, A. nobilis Bunge ex B. Fedtsch.

Linaceae: Linum macrohizum Juz.

Euphorbiaceae: Andrachne Fedtschenkoi Koss., Euphorbia polytimetica Prokh.

Rhamnaceae: Rhamnus coriacea (Regel) Kom.

Violaceae: Viola alaica Vved., V. majchurensis Pissjauk.

Elaeagnus: Elaeagnus songarica Bernh. Ex Schlecht.

Umbelliferae: Seseli seravschanicum M. Pimen. et Sdobn., Conioselinum schugnanicum B. Fedtsch., Ferula Linczevskii Korov., Semenovia bucharica (Schischk.) Mandel., Lepechiniella sarawschanica (Lipsky) M. Pop., Eritrichium subjacquemontii M. Pop., Rochelia claviculata M. Pop. Et Zak.

Limoniaceae: Acantholimon parviflorum Regel, A. Komarovii Czerniak. ex Lincz, A. velutinum Czerniak. ex Lincz, Limonium Komarovii Ik.-Gal. ex Linch. et Czuk., Eremolimon Fajzievii (Zak. Ex Lincz.) Lincz.

Labiatae: Scutellaria picta Juz., S. haesitabunda Juz., S. poëcilantha Nevski et Juz., S. rubromaculata Juz. et Vved., S. orbicularis Bunge, Nepeta tytthantha Pojark., N. maussarifi Lipsky, Eremostachys sarawschanica Regel, E. mogianica M. Pop., Lagochilus kschtutensis Knorr., Salvia Komarovii Pobed.

Rubiaceae: Asperula pamirica Pobed., A. Czukaviniae Pahom. et Karim., Galium Vassilczenkoi Pobed.

Valerianaceae: Valeriana Kamelinii B. Sharipova

Campanulaceae: Campanula Lehmanniana v. integerrima Bunge, C. hissarica R. Kam., Asyneuma baldshuanicum (O. Fedtsch.) Fed., A. debile Fed., A. attenuatum (Franch.) Bornm., Cryptocodon monocephalus (Trautv.) Fed.

Compositae: Inula glauca C. Winkl., Cousinia ulotoma Bornm., C. princeps Franch., C. sarawschanica C. Winkl., C. splendida C. Winkl., Jurinea Komarovii Iljin, Cirsium Rassulovii B. Sharipova, Scorzonera Albertoregelia C. Winkle., Taraxacum Kovalevskiae Vainberg, T. pseudobrevirostre Vainberg, T. seravschanicum Schischk., T. Vassilczenkoi Schischk. 


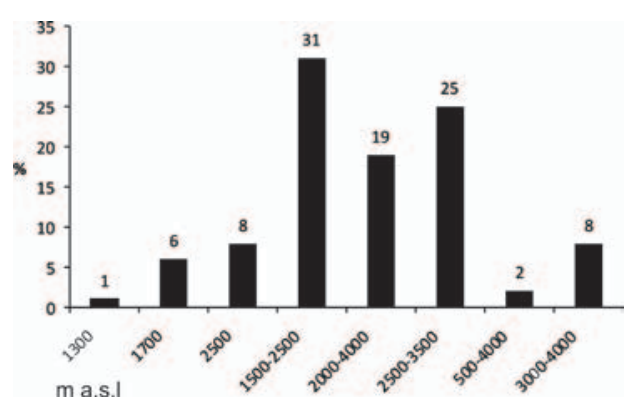

Fig. 2. Distribution of endemic species in vegetation belts in the area of central part of Zeravshan sub-region: I - zone of sage and saltwort deserts, II - zone of sage desert and juniper forests, III - zone of steppes juniper forests and torn vegetations, IV - zone of cushion plant formation and torn vegetations.

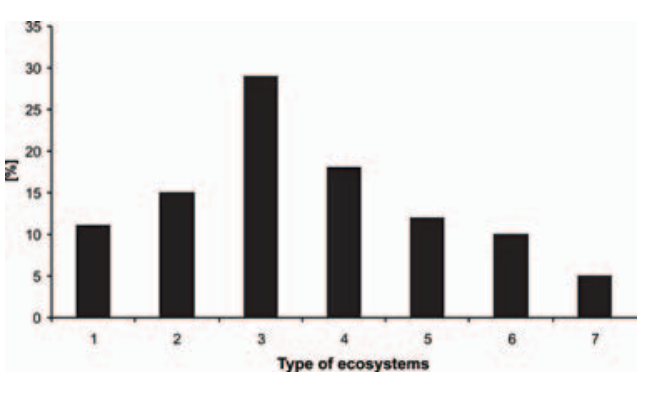

Fig. 3. The number of endemic species in main type of ecosystems in central part of Fann Mountains: 1 - High mountain desert, 2 - high mountain meadow and steppes, 3 - midmountain conifer forests, 4 - mid-mountain mesophyllics forest, 5 - mid-mountain xerophytic light forests, 6 - midlow-mountain semi-savanna and, 7 - wetland ecosystems.

to the genera with the highest number of endemic plants: Astragalus, Oxytropis, Cousin, Potentilla, Scutellaria, Taraxacum, Delphinium, Ranunculus, Acontholimon, Nepeta. The remaining genera amount to only two species or one species.

Most endemic plants occur at heights 1500-4000 m a.s.l. Contribution of these species within the distinguished plant levels is presented in Fig. 2. Endemic plants grow also below and above the accepted ranges of height.

The contribution of endemic species is also observed within particular type of ecosystems (Fig. 3). Mid-mountain juniper forest created suitable ecological niches for many endemic species in this region.

In the area of the Zeravshan Mountains, apart from 'local' endemic plants, there are also endemic species of adjacent areas (Abdysalyamov, 1988). There are often narrow endemic species: Asplenium pseudofontanum C. Koss., Lonicera paradoxa Pojark., Gagea holochiton M. Pop. et Czuk., Tulipa Micheliana Hoog, Ferula sumbul, Zeravschania Regeliana.

Quite significant differences in the distribution of endemic plants within geobotanic sub-districts were stated. Most endemic plant species occur in the central and eastern part of area, which is associated with differences in habitat, as well as the specific climatic conditions within the limits of mountain ridges and valleys. The smallest number of endemic species is in the western part, which is affected by a relatively small height above sea level, and the presence of wide valleys used for agriculture, which was not observed in the central and eastern parts.

In terms of life forms, among endemic plants of that area, perennial, plants and shrubs, biennials, trees and annual species predominate respectively. All these species are characterized by specific features of adaptations to life in extreme mountain conditions. They are frequently characterized by a structure of xeromorphic type and a growth of a cushion-shaped type, shrub-line (lanes shrubs), turf, rosetted, miniature, oligomerization, hairiness succulent, waxy-leaved and perennial. 


\section{Discussion and conclusion}

Geographical location of Fann Mountains in the southern arid zone and high mountain systems among continental deserts of Eurasia with combination of latitude zonation, vertical belts from hot deserts, sub-tropics to permafrost, and geographical zones condition due to this region diverse in term of landscapes and biological diversity.

One of the reasons of biodiversity and phenomenon of endemism is associated with the presence of orographic barriers, such as the Zeravshan Range. High mountain ranges hinder the migration of animal and plant spreading. Consequently, isolated populations can easily evolve into separate species. The great glacial cirques and deep valleys, occurring between mountain ranges, are characterized by specific climatic and soil conditions which affect the occurrence of the species which are not found in other ecosystems.

Juniper forests are highly important: on the one hand, they have the water-protective and anti-erosion function, and on the other, they serve as the source of high-quality construction, carpentry timber and fuel wood. Nowadays, the archovnik (juniper forest) forests of Tajikistan, including those of Kulikalon Lake in central parts of Fann Mountains, are severely disturbed because of unregulated and excessive cuttings as well as by grazing which present obstacles to a natural regeneration of archa (Juniper). It will be recalled that all forest ecosystems of Tajikistan refer to the first category, as they have the nature-conservation and soil-protection role, and their cutting is strictly prohibited. Currently, however, because of a shortage of fuel, there has been a clear cutting of forests (including illegal cutting, as is the case in Kulikalon Lake and in its environs). This, in turn, has a negative influence on landscape diversity, biodiversity and forest regeneration processes, enhancing erosion on the slopes and the degradation of soils.

Because of the differentiation of landforms and micro- and topo-climate, the vegetation ecosystems of the Fann Mountains, there are distinguished different types of plant communities, and diverse species compositions and landscape complexes. The juniper forests constitute the main landscape component of the whole of Zeravshan geobotanical region. On the territory of the Fann Mountains, only very small juniper forest tracts are not disturbed by human economic activity. Woody forms of Juniperus semiglobosa, J. turkestanica, and J. seravschanica have been mostly clear-cut. As a result, the process of soil erosion on steep slopes intensified, which affected in consequence the species composition of herbaceous plants.

High-mountain environment of the Zeravshan Mountains, like any other environment of that type, is very sensitive to external influences, both natural and anthropogenic. In addition, the organic world and soils of this area function under arid conditions (mountain semi-desert). Ecosystems of juniper forests develop very slowly and specimens of juniper grow for hundreds of years, sometimes reaching 1000 years. Taking into account biomass, canopy, shade and other environmental circumstances, they are the basic link in the system of biocenotic connections of this region (Ismailov, 1974). Thus, the cutting of these trees is a mechanism causing the degradation of this ecosystem containing the endemic plants. Moreover, the juniper forests play an important protective role in relation to surrounding ecosystems (Rahmonov et al., 2011a). 
The highest peak of the Fann Mountains, Chimtarga (5495 m a.s.l.), is one of the most frequently visited touristic attractions and hence it is under increasing anthropogenic pressure. Its most destructive forms in central part of analysed region include grazing, illegal felling for firewood and construction purposes as well as unorganized forms of tourism.

\section{References}

Abdusalyamov, I.A. (Ed.), (1988). Red Data Book of Tadjik SSR (in Russian). Dushanbe: Donish Press.

Atlas of Tajik SSR (in Russian) (1968). Dushanbe-Moscow: GUGiK.

Chukavina, A.P. (Ed.), (1984). Flora of Tajik SSR. Vol. VII (in Russian). Leningrad: Nauka Press.

Goncharov, N.F. (1937). Floristical regions of Tajikistan and their vegetation (in Russian). In P.N. Ovchinnikov (Ed.), Flora Tajik SSR. Vol. V (pp. 20-45). Moscow-Leningrad:Soviet Science Press.

Ismailov, M.I. (1974). Botanical and geographical review of Junipers L. with connection their origin and development in Russian). In M.I. Ismailov (Ed.), Ecological problems and vegetation geography (pp.15-40). Dushanbe: Donish Press

Kamelin, R.V. (1979). Mountains regions of Central Asia (in Russian). Leningrad: Nauka Press.

Kinzikaeva, G.I. (Ed.), (1988). Flora of Tajik SSR. Vol. IX (in Russian). Leningrad: Nauka Press.

Kochkareva, T.F. (Ed.), (1986). Flora of Tajik SSR. Vol. VIII (in Russian). Leningrad: Nauka Press.

Konnov, A.A. (1973). The flora of juniper forests of Shakhristan (in Russian). Dushanbe: Donish Press.

Kudratov, I. (1985). The lichens of Upper Zeravshan (in Russian). Dushanbe: Donish Press.

Meyers, N., Mittermeier, R.A., Mittermeier, C.G., Da Fonseca, G.A.B. \& Kent J. (2000). Biodiversity hotspots for conservation priorities. Nature, 403, 853-858. doi:10.1038/35002501

Mittermeier, R.A. Myers, N., Gil, P.R. \& Mittermeier C.G. (2005): Hotspots Revisited: Earth's Biologically Richest and Most Endangered Terrestrial Ecoregions. Washington D.C.: Conservation International.

Ovchinnikov, P.N. (1957). The main character vegetation and floristic regions of Tajikistan (in Russian). In P.N. Ovchinnikov (Ed.), Flora of Tajik SSR. Vol. VII (pp. 1-15). Leningrad: Nauka Press.

Ovchinnikov, P.N. (Ed.), (1957, 1963, 1968, 1975, 1978, 1981). Flora of Tajik SSR. Vol. I-VI (in Russian). Leningrad: Nauka Press.

Rahmonov, O., Rahmonova, M., Snytko, V.A. \& Szczypek T. (2011a). Anthropogenic disturbance to vegetation on the polygon-transect in the Kulikalon depression (Tajikistan). Geography and Natural Resources, 32(4), 386393. DOI: $10.1134 / \mathrm{S} 1875372811040147$.

Rahmonov, O., Snytko, W.A., Szczypek, T. \& Kłys G. (2011b). Influence of human impact on the vegetation of the northern part of Fann Mountains (a case study of Kulikalon Basin) (in Polish). Acta Geographica Silesiana, 10, 64-73.

Rasulova, M.R. (Ed), (1991). Flora of Tajik SSR. Vol. X (in Russian). Leningrad: Nauka Press.

Safarov, N.O. (1974). About phytocenological features of birch forests in catchment of Iskandarkul Lake (in Russian). The materials of young scientifics conference of Tajik SSR (Biology Section) (pp. 37-39). Dushanbe: Donish Press.

Sidorenko G.T., Strizheva T.G. \& Chukavina A.G. (1964). The vegetation of Zeravshan River catchment (in Russian). In P.N. Ovchinnikov (Ed.), The materials for rational land use in Tajikistan (pp. 113-129). Dushanbe: Tajik SSR Academy of Science.

Stanyukovich, K.V. (1973). Vegetation of mountains of USSR (in Russian). Dushanbe: Donish Press. 